\title{
THE PLACEMENT OF EXTRA-CLAUSAL CONSTITUENTS IN FUNCTIONAL DISCOURSE GRAMMAR*
}

\author{
Evelien Keizer \\ University of Vienna
}

\begin{abstract}
Although Functional Discourse Grammar offers a detailed set of placement rules for the linear ordering of elements within the clause, phrase and word, little attention has been paid to the placement of extra-clausal constituents (EECs). Thus, so far there has been no systematic attempt to link the rhetorical or discourse-pragmatic functions of EECs to the position they take vis-à-vis (elements of) their host; nor has there been any attempt to integrate any observations about the position of ECCs into the general placement rules proposed in FDG. Using authentic data from various corpora of English, this paper shows that FDG can capture the (interaction between the) various interpersonal, contextual and processing factors that determine the linear placement of EECs. In addition it is argued that the placement of EECs can be integrated into the placement rules of FDG, provided that a third extra-clausal position (interpolated) is distinguished for ECCs interrupting the host. KEYwORDs: extra-clausal constituents, rhetorical function, information structure, linear ordering, processing.
\end{abstract}

\section{EL ORDEN DE LOS CONSTITUYENTES EXTRA-CLAUSALES EN LA GRAMÁTICA DISCURSIVO-FUNCIONAL}

\section{RESUMEN}

Aunque la Gramática Discursivo-Funcional ofrece un conjunto detallado de reglas de colocación para establecer el orden lineal de los elementos dentro de la oración, frase y palabra, el orden de los constituyentes extra-clausales (CECs) ha recibido poca atención. Así, hasta el momento no ha habido ningún intento sistemático de relacionar las funciones retóricas y pragmático-discursivas de los CECs con la posición que estos ocupan con respecto a (elementos de) la unidad que los alberga; tampoco ha habido ningún intento de integrar las observaciones sobre su posición en las reglas generales de colocación de la GDF. Usando datos reales extraídos de varios corpus del inglés, este artículo muestra cómo la GDF puede dar cuenta de (la interacción entre) los distintos factores interpersonales, contextuales y de procesamiento que determinan la colocación de los CECs. Asimismo, se sostiene que el orden de los CECs puede integrase en las reglas de colocación de la GDF, siempre que se distinga una tercera posición extra-clausal (intercalada) para los CECs que interrumpen la unidad que los alberga.

Palabras Clave: constituyentes extra-clausales, función retórica, estructura de la información, orden lineal, procesamiento.

DOI: https://doi.org/10.25145/j.recaesin.2020.80.06

Revista Canaria de Estudios Ingleses, 80; April 2020, pp. 89-121; ISSN: e-2530-8335 


\section{INTRODUCTION}

Unlike most functional (and cognitive) theories or approaches, Functional Discourse Grammar (FDG) offers a detailed set of placement rules for the exact linear ordering of elements within the clause, phrase and word. In accordance with the directional function-to-form nature of the theory as a whole, these rules apply in a top-down, hierarchical manner, with units representing (inter)subjective, discoursepragmatic or rhetorical information being assigned a position before units from lower levels and layers, representing various kinds of semantic information (Hengeveld \& Mackenzie, Functional 309-310; Keizer, A Functional 184-185).

One thing that is still missing, however, is a systematic approach to the placement of what Dik (The Theory I 310-211) calls "extra-clausal constituents" (ECCs), often also referred to as "parenthetical elements", "disjuncts" or "theticals", i.e. "elements that are not part of the clause proper, but more loosely connected with it in ways which can most adequately be described in terms of pragmatic functionality" (The Theory I310; see also The Theory II 379). Consider, for instance, the italicized expressions in (1), which consist of two units that are semantically (i.e. truth-conditionally), syntactically and prosodically independent, but which are nevertheless related at some discourse-pragmatic or discourse-organizational level:
a. As for the students, they won't be invited.
b. I'm afraid, Peter, that you are going a bit too fast.
c. John was, so they say, a bright student.
d. He's a nice chap, your brother.
(examples from Dik, The Theory I 311; see also Hengeveld \& Mackenzie, Functional 55-58)

In FDG, the italicized elements in (1) have been analysed in different ways. The expressions in (1a) and (1d) have been analysed as separate (Subsidiary) Discourse Acts with a rhetorical function expressing the specific relation to their host (or Nuclear Discourse Act): Orientation in (1a) (Hengeveld \& Mackenzie, Functional 55) and Correction (Hengeveld \& Mackenzie, Functional 56) or Clarification (Dik, The Theory I311) in (1d). Vocatives like Peter in (1b), on the other hand, have been analysed as the lexical head of the Addressee participant in an independent Interpellative Discourse Act (see Section 4.2). In other cases, such as so they say in (1c), the expression has been analysed as a modifier of an interpersonal layer (in this case, a reportative modifier at the layer of the Communicated Content; Hengeveld \& Mackenzie, Functional 103; Keizer, "The interpersonal level" 856).

* I am very grateful to Riccardo Giomi and Matthias Klumm for their valuable comments on an earlier version of this paper, many of which have, in some way or other, been included in the present version. All remaining errors are naturally entirely my own. 
However, although some attention has been paid to the analysis of ECCs and their rhetorical or discourse-pragmatic functions, little has been said about the relation between these functions and the position ECCs take with regard to (elements of) their host. Nor has there been any attempt to integrate any observations about the exact position of ECCs (in particular the interpolated ones in (1b\&c)) into the general placement rules proposed in FDG.

Using authentic data from various corpora of English (Davies, The British National Corpus (BYU-BNC); Davies, The Corpus of Contemporary American English (COCA); Davies, News on the Web Corpus (NOW)), the current paper attempts to fill this gap (partly at least) by addressing the following questions:

- Which interpersonal and contextual factors influence the placement of ECCs visà-vis (constituent parts of) their host (Nuclear Discourse Act)?

- How can any tendencies observed in the placement of these elements be integrated in the placement rules of FDG?

The structure of the paper is as follows. First, Section 2 provides a general overview of the relevant aspects of the theory of Functional Discourse Grammar, in particular its top-down, hierarchical organization, its different levels and layers of analysis, and its interaction with other, non-linguistic components. Section 3 subsequently describes how the theory's hierarchical organization is used to account for the linear ordering of constituents. Section 4 presents a summary of how ECCs have been dealt with in Functional Grammar (Dik, The Theory I, The Theory II) and Functional Discourse Grammar (Hengeveld \& Mackenzie, Functional). Next, Section 5 examines the various factors involved in the placement of several types of ECCs, and shows how an FDG analysis incorporating these factors can account for their position vis-à-vis the clause. Section 6 concludes the paper.

\section{FUNCTIONAL DISCOURSE GRAMMAR: BRIEF INTRODUCTION}

\subsection{General Characterization}

Functional Discourse Grammar, the successor of Dik's (The Theory I, The Theory II) Functional Grammar, has been characterized as a "structural-functional" theory of language (Butler 30), in that "it seeks to reconcile the patent fact that languages are structured complexes with the equally patent fact that they are adapted to function as instruments of communication between human beings" (Hengeveld \& Mackenzie, Functional ix; cf. Dik The Theory I 3). The result is what Hengeveld \& Mackenzie (Functional 26) describe as "a form-oriented function-to-form" model. FDG is "function-to-form" in the sense that, in a top-down fashion, the model starts with the Speaker's communicative intention and from there works its way down to articulation. In this way, "FDG takes the functional approach to language to its logical extreme", as pragmatics is taken to govern semantics, pragmatics and 
semantics to govern morphosyntax, and pragmatics, semantics, and morphosyntax to govern phonology (Hengeveld \& Mackenzie, Functional 13). At the same time, however, FDG is "form-oriented", in that it only seeks to account for those pragmatic and semantic phenomena that are reflected in the morphosyntactic and phonological form of an utterance (e.g. Hengeveld \& Mackenzie, Functional 39; 40).

The privileged role of pragmatics is further reflected in the fact that FDG takes as its basic unit of analysis not the clause (a morphosyntactic unit), but the Discourse Act (a communicative unit; see also below). This means that FDG can accommodate not only regular clauses, but also units larger than the clause, such as complex sentences, and units smaller than the clause, such as interjections or single phrases. Moreover, in order to represent all linguistic information relevant for the formation of a linguistic expression, FDG analyses Discourse Acts in terms of independent pragmatic, semantic, morphosyntactic and phonological modules, which interact to produce the appropriate linguistic expression. Together, these four levels, and the primitives feeding into these levels, form the grammatical component of the model (the FDG proper; see Figure 1).

The grammatical component, however, does not operate in isolation, but interacts with three extra-linguistic components: a contextual component, containing non-linguistic information about those aspects of the immediate discourse context that affect the form of a linguistic utterance (see also Connolly, "Context", "The Contextual Component"; Cornish; Alturo et al.; Hengeveld \& Mackenzie, "Grammar"); a conceptual component, which contains the prelinguistic conceptual information relevant for the production of a linguistic expression, and which forms the driving force behind the grammatical component (see e.g. Connolly, "The Contextual Component"); and an output component, consisting of spoken, signed or written forms. A general outline of the model is given in Figure 1.

\subsection{Four LEVELS OF ANALYSIS}

The four levels of representation used in FDG are the outcome of two types of operations: Formulation and Encoding, dealing with meaning and form, respectively. The operation of Formulation results in representations at the first two levels, which capture all the relevant pragmatic and semantic aspects of a linguistic expression. The operation of Encoding subsequently takes care of an expression's morphosyntactic and phonological properties. Each of the four levels is hierarchically organized into a number of different layers.

The highest level of representation is the Interpersonal Level (IL), which deals with "all the formal aspects of a linguistic unit that reflect its role in the interaction between the Speaker and the Addressee" (Hengeveld \& Mackenzie, Functional 46). The most inclusive layer at this level is the Move (M), which forms "the largest unit of interaction relevant to grammatical analysis" (Hengeveld \& Mackenzie, Functional 50). Each Move consists of one or more Discourse Acts (A), defined as "the smallest identifiable units of communicative behaviour" which, unlike Moves, "do not necessarily further the communication in terms of approaching a conversational 


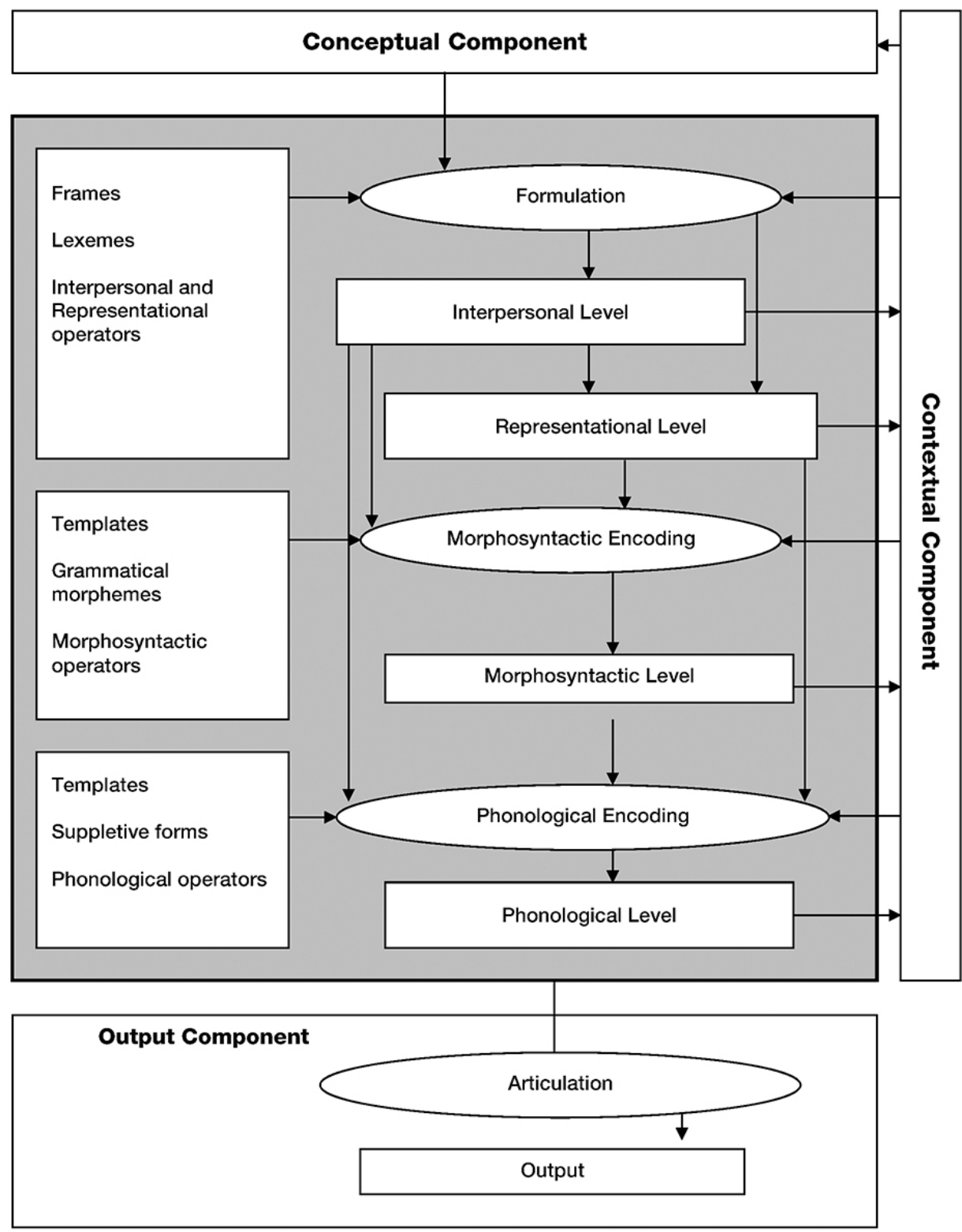

Figure 1: General layout of FDG (based on Hengeveld \& Mackenzie, Functional 13).

goal" (Kroon 85; Hengeveld \& Mackenzie, Functional 60). These Discourse Acts, in turn, consist of an Illocution $(\mathrm{F})$, the Speech Participants $\left(\mathrm{P}_{1}\right.$ and $\mathrm{P}_{2}$, representing the speaker and the addressee) and a Communicated Content (C), which "contains 
the totality of what the Speaker wishes to evoke in his/her communication with the Addressee" (Hengeveld \& Mackenzie, Functional 87). Within the Communicated Content, one or more Subacts of Reference (R) and Ascription (T) are evoked by the Speaker. In addition, each of these layers is provided with a slot for operators and modifiers, providing additional grammatical and lexical information, respectively, about the layer in question. ${ }^{1}$

To illustrate the kind of information that is dealt with at the Interpersonal Level, and the kind of units (layers) distinguished at this level, consider the sentence in (2):

a. I frankly cannot afford a holiday this year.

b. $\quad\left(\mathrm{M}_{\mathrm{I}}:\left(\mathrm{A}_{\mathrm{I}}:\left[\left(\mathrm{F}_{\mathrm{I}}: \operatorname{DECL}\left(\mathrm{F}_{\mathrm{I}}\right)\right.\right.\right.\right.$ : frankly $\left.\left(\mathrm{F}_{\mathrm{I}}\right)\right)\left(\mathrm{P}_{\mathrm{I}}\right)_{S}\left(\mathrm{P}_{\mathrm{J}}\right)_{\mathrm{A}}\left(\mathrm{C}_{\mathrm{I}}:\left[\left(\mathrm{T}_{\mathrm{I}}\right)_{\mathrm{FOC}}\left(+\mathrm{id} \mathrm{R}_{\mathrm{I}}\right.\right.\right.$ : $\left.\left.\left.\left.\left.\left.[+S, A]\left(\mathrm{R}_{\mathrm{I}}\right)\right)\left(-\mathrm{id} \mathrm{\textrm {R } _ { \mathrm { J } }}:\left(\mathrm{T}_{\mathrm{J}}\right)\left(\mathrm{R}_{\mathrm{J}}\right)\right)\left(+\mathrm{id} \mathrm{R}_{\mathrm{k}}:\left(\mathrm{T}_{\mathrm{K}}\right)\left(\mathrm{R}_{\mathrm{k}}\right)\right)\right]\left(\mathrm{C}_{\mathrm{I}}\right)\right)\right]\left(\mathrm{A}_{\mathrm{I}}\right)\right)\left(\mathrm{M}_{\mathrm{I}}\right)\right)$

In (2b) we find a Move $\left(M_{I}\right)$, consisting of a single Discourse Act $\left(A_{\mathrm{r}}\right)$, which in turn consists of an Illocution $\left(\mathrm{F}_{\mathrm{I}}\right)$, the two Speech Participants $\left(\mathrm{P}_{1}\right.$ and $\left.\mathrm{P}_{2}\right)$, and a Communicated Content $\left(\mathrm{C}_{\mathrm{T}}\right)$. Since we are dealing with a declarative sentence, the Illocution $\left(\mathrm{F}_{\mathrm{I}}\right)$ has the abstract head DECL; in addition, the Illocution is modified by the illocutionary adverb frankly (Hengeveld \& Mackenzie, Functional 82; Keizer, "Interpersonal adverbs", "The semantics"). The Communicated Content consists of three Subacts of Reference, one evoking the speaker $\left(\mathrm{R}_{\mathrm{I}}\right)$, one evoking the entity described as a holiday $\left(\mathrm{R}_{\mathrm{J}}\right)$ and one evoking the temporal entity described as this year $\left(\mathrm{R}_{\mathrm{K}}\right)$, as well as three Subacts of Ascription, one evoking the property 'afford' ( $\mathrm{T}_{\mathrm{r}}$, which, as the element presenting the most salient information is assigned the pragmatic function Focus), and the other two evoking the Properties 'holiday' $\left(\mathrm{T}_{\mathrm{J}}\right)$ and 'year' $\left(T_{K}\right)$ (assigned to the referents evoked by $R_{L}$ and $R_{K}$, respectively). Two of the Subacts of Reference, $R_{I}$ and $R_{K}$, are specified by the operator $+i d$, indicating the speaker assumes the addressee to be able to identify the referent evoked; the third, $\mathrm{R}_{\mathrm{J}}$, is marked as unidentifiable.

The second level of Formulation, the Representational Level (RL), deals with the semantic aspects of a linguistic expression, i.e. with those aspects of a linguistic expression that reflect the way in which language relates to the (real or imagined) world it describes (cf. Halliday and Hasan's ideational metafunction). The units at this level represent the different linguistically relevant types of entities in the extralinguistic world (Hengeveld \& Mackenzie, Functional 131; cf. Lyons 442-447). The highest layer at this level is that of the Propositional Content (p), which represents a mental construct which can be evaluated in terms of its truth. The Propositional Content consists of one or more Episodes (ep), i.e. sets of States-of-Affairs (e) that

${ }^{1}$ For distinguishing between operators and modifiers, FDG relies on two criteria: modifiability (modifiers can themselves be modified, operators cannot); and focality (modifiers can be focalized, operators cannot). Note that the use of two criteria also leads to the distinction of a third group, consisting of elements that are focalizable but not modifiable (lexical operators; see Keizer, "The grammatical-lexical"; Hengeveld). 
are coherent in terms of time, space and participants. Each State-of-Affairs (e) is, in turn, characterized by a Configurational Property $(\mathrm{f})$, consisting typically of a lexical (typically verbal) Property ( $\left.f^{\prime}\right)$ and one or more arguments. These arguments, which may refer to any type of entity, are typically headed by a nominal lexical property. Here, too, each layer is provided with a slot for operators and modifiers, the former expressing grammatical information (e.g. tense, aspect, modality or number), the latter additional lexical information (e.g. manner, time or place adverbs) concerning the layer in question.

A Representational Level analysis of sentence in (2a) above is provided in (3):

$\left(\mathrm{p}_{\mathrm{p}}:\left(\right.\right.$ pres ep $\mathrm{p}_{\mathrm{i}}$ : (neg e $\mathrm{e}_{\mathrm{i}}$ : (abil $\mathrm{f}_{\mathrm{i}}^{\mathrm{c}}$ : $\left[\left(\mathrm{f}_{\mathrm{i}}^{1}\right.\right.$ : afford $\left.\left(\mathrm{f}_{\mathrm{i}}^{\mathrm{f}}\right)\right)\left(\operatorname{sing} \mathrm{x}_{\mathrm{i}}\right)_{\mathrm{A}}\left(\operatorname{sing} \mathrm{e}_{\mathrm{j}}:\left(\mathrm{f}_{\mathrm{j}}^{1}\right.\right.$ : holiday $\left.\left.\left.\left.\left.\left(\mathrm{f}_{\mathrm{j}}^{\mathrm{l}}\right)\right)\left(\mathrm{e}_{\mathrm{j}}\right)\right)_{\mathrm{U}}\right]\left(\mathrm{f}_{\mathrm{i}}^{\mathrm{c}}\right)\right)\left(\mathrm{e}_{\mathrm{i}}\right)\right)\left(\mathrm{ep}_{\mathrm{i}}\right):\left(1\right.$ prox $\mathrm{t}_{\mathrm{i}}:\left(\mathrm{f}_{\mathrm{k}}^{\mathrm{l}}:\right.$ year $\left.\left.\left.\left.\left(\mathrm{f}_{\mathrm{k}}^{1}\right)\right)\left(\mathrm{t}_{\mathrm{i}}\right)\right)\left(\mathrm{ep}_{\mathrm{i}}\right)\right)\left(\mathrm{p}_{\mathrm{i}}\right)\right)$

The highest layer of analysis here is the Propositional Content $\mathrm{p}_{\mathrm{i}}$. This Propositional Content contains a single Episode ep, which in turn consists of a single States-of-Affairs $e_{i}$. This State-of-Affairs is headed by a Configurational Property $f_{i}^{c}$, consisting of the verbal Property afford $\left(\mathrm{f}_{i}^{1}\right)$ and its two arguments (the Individual $I$, represented as $\mathrm{x}_{\mathrm{i}}$, and another State-of-Affairs, a holiday, represented as $\mathrm{e}_{\mathrm{j}}$ ). The representation further contains a modifier (the time denoting element this year, $\mathrm{t}_{\mathrm{i}}$, modifying the Episode), and a number of operators: the tense operator 'present' at the layer of the Episode, the negation operator 'neg' at the layer of the State-ofAffairs, the facultative participant-oriented modality operator 'abil' at the layer of the Configurational Property (see Hengeveld \& Mackenzie, Functional 212; Dall'Aglio Hattnher \& Hengeveld) and the singularity modifier 'sing', indicating number for the countable entities $\mathrm{x}_{\mathrm{i}}, \mathrm{e}_{\mathrm{j}}$ and $\mathrm{t}_{\mathrm{i}}{ }^{2}$ Finally, the two arguments $\mathrm{x}_{\mathrm{i}}$ and $\mathrm{e}_{\mathrm{j}}$ are provided with a semantic (macro-)role, Actor (A) and Undergoer (U), respectively.

The output of the operation of Formulation forms the input to the operation of Encoding; at this stage, it is no longer possible to add or change any meaning components to the utterance. The first level of Encoding, the Morphosyntactic Level $(\mathrm{ML})$, accounts for all the morphosyntactic and linear properties of the linguistic units triggered by the two levels of Formulation. The largest unit of analysis at this level is that of the Linguistic Expression (Le), which typically contains one or more Clauses and/or Phrases. Clauses (Cl), in turn, may consist of one or more Phrases and Words, as well as of other Clauses. Phrases may contain one or more Words, as well as other Phrases or Clauses. Words, finally, consist of one or more Morphemes (not included in the analysis below). Phrases, Words and Morphemes are further categorized on the basis of the kind of head they have. Thus there are, for instance, Verbal Phrases (Vp), Nominal Phrases (Np) and Adjectival Phrases (Ap), as well as Verbal Words $(\mathrm{Vw})$, Nominal Words $(\mathrm{Nw})$ and Adjectival Words (Aw). In addition,

2 In standard FDG the operator ' 1 ' is used to indicate both singularity and the numeral one; to distinguish between the two, Keizer ("English partitives" 33) introduces the operator 'sing' for singularity. 
there are Grammatical Words (Gw), which typically correspond to operators at the levels of Formulation. Finally, it is at this level that the syntactic functions Subject and Object are assigned. A morphosyntactic analysis of the sentence in (2a) is given in (4):

$\left(\operatorname{Le}_{\mathrm{i}}:\left(\mathrm{Cl}_{\mathrm{i}}:\left[\left(\mathrm{Np}_{\mathrm{i}}:\left(\mathrm{Nw}_{\mathrm{i}}: \mathrm{I}\left(\mathrm{Nw}_{\mathrm{i}}\right)\right)\left(\mathrm{Np}_{\mathrm{i}}\right)\right)_{\text {Subj }}\left(\mathrm{Vw}_{\mathrm{i}}: \operatorname{can}\left(\mathrm{Vw}_{\mathrm{i}}\right)\right)\left(\mathrm{Gw}_{\mathrm{i}}: \operatorname{not}\left(\mathrm{Gw}_{\mathrm{i}}\right)\right)\right.\right.\right.$ $\left(\mathrm{Vp}_{\mathrm{i}}\right.$ : $\left(\mathrm{Vw}_{\mathrm{i}}\right.$ : afford $\left.\left.\left(\mathrm{Vw}_{\mathrm{j}}\right)\right)\left(\mathrm{Vp}_{\mathrm{i}}\right)\right)\left(\mathrm{Np}_{\mathrm{i}}:\left[\left(\mathrm{Gw}_{\mathrm{i}}: \mathrm{a}\left(\mathrm{Gw}_{\mathrm{i}}\right)\right)\left(\mathrm{Nw}_{\mathrm{i}}\right.\right.\right.$ : holiday $\left.\left.\left(\mathrm{Nw}_{\mathrm{i}}\right)\right)\right]$ $\left.\left(\mathrm{Np}_{\mathrm{j}}\right)\right)_{\text {obj }}\left(\mathrm{Np}_{\mathrm{k}}:\left[\left(\mathrm{Gw}_{\mathrm{k}}\right.\right.\right.$ : this $\left.\left(\mathrm{Gw}_{\mathrm{k}}\right)\right)\left(\mathrm{Nw}_{\mathrm{k}}\right.$ : year $\left.\left.\left.\left.\left.\left.\left(\mathrm{Nw}_{\mathrm{k}}\right)\right)\right]\left(\mathrm{Np}_{\mathrm{k}}\right)\right)\right]\left(\mathrm{Cl}_{\mathrm{i}}\right)\right)\left(\mathrm{Le}_{\mathrm{i}}\right)\right)$

Finally, the Phonological Level converts the input from the three higher levels into phonological form. Once again the layers at this level are hierarchically organized. The highest layer, the Utterance (U) consists of one or more Intonational Phrases (IP), which in turn consist of Phonological Phrases (PP) (which divide into Phonological Words, which are made up of Feet, which contain Syllables; these are not included in the representation below). The layer that is most relevant for the current discussion is that of the Intonational Phrase, which, in the default case, corresponds to a Discourse Act at the Interpersonal Level. Intonational Phrases are characterized internally by the presence of a complete intonational contour, and externally by the presence of intonational boundaries. A possible (simplified) phonological representation of example (2a) is given in (5). This representation contains one operator, ' $\mathrm{f}$ ', indicating a falling intonation at the layer of the Intonational Phrase (triggered by the presence of a Declarative Illocution at the IL).

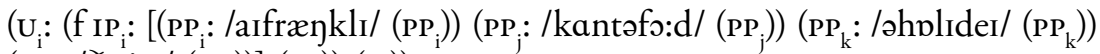

$$
\begin{aligned}
& \left.\left.\left.\left(\mathrm{PP}_{\mathrm{i}} \text { / / } / \mathrm{sj} \mathrm{j} / 2 /\left(\mathrm{PP}_{\mathrm{l}}\right)\right)\right]\left(\mathrm{IP}_{\mathrm{i}}\right)\right)\left(\mathrm{U}_{\mathrm{i}}\right)\right)
\end{aligned}
$$

\section{LINEAR ORDERING IN FUNCTIONAL DISCOURSE GRAMMAR}

Where in the framework of Functional Grammar Dik (The Theory I 399415) provided a list of general and specific universal principles for the ordering of constituents (LIPOC), ${ }^{3}$ FDG offers a set of functionally-inspired, to some extent language specific, placements rules. Guided by the general tendencies observed by Dik, these rules provide a more precise account of the possibilities of and restrictions on the ordering of elements within the clause, phrase and word. The system proposed is functional in that the placement of constituents is (almost) entirely determined by information contained in the higher two levels, with elements being placed in a top-down, outward-inward manner (Hengeveld \& Mackenzie, Functional 310316; Keizer, A Functional 184-191); in other words, units from the Interpersonal

\footnotetext{
${ }^{3}$ Language independent preferred order of constituents.
} 
Level are placed before units from the Representational level, and, within each level, hierarchically higher (more inclusive) layers before lower (inner) layers.

Another distinction relevant for the ordering of element is that between core and non-core units, ${ }^{4}$ i.e. between elements within and outside the head of the Communicated Content at the Interpersonal level (content frame) and within and outside the head of the Configurational Property at the Representational Level (predication frame):

$$
\left(\mathrm{M}_{1}:\left(\mathrm{A}_{1}:\left[( \mathrm { F } _ { 1 } ) ( \mathrm { P } _ { 1 } ) _ { S } ( \mathrm { P } _ { 2 } ) _ { \mathrm { A } } \left(\mathrm{C}_{1}: \underset{\begin{array}{c}
\text { Content Frame } \\
\text { (core unit) }
\end{array}}{\left.\left.\left.\left.\stackrel{\left.\ldots\left(\mathrm{T}_{1}\right)\left(\mathrm{R}_{1}\right) \ldots\right]}{\longrightarrow}\left(\mathrm{C}_{1}\right)\right)\right]\left(\mathrm{A}_{1}\right)\right)\left(\mathrm{M}_{1}\right)\right)}\right.\right.\right.\right.
$$

$$
\left(\mathrm{p}_{1}:\left(\mathrm{ep}_{1}:(\mathrm{e}_{1}: \underbrace{\left.\left.\left(\mathrm{f}_{1}^{\mathrm{c}}:\left[\left(\mathrm{f}_{1}^{1}\right)\left(\mathrm{x}_{1}\right)\left(\mathrm{x}_{2}\right) \ldots\right]\left(\mathrm{f}_{1}^{\mathrm{c}}\right)\right)\left(\mathrm{e}_{1}\right)\left(\mathrm{ep}_{1}\right)\right)\left(\mathrm{p}_{1}\right)\right)}_{\begin{array}{c}
\text { Predication Frame } \\
\text { (core unit) }
\end{array}}\right.\right.
$$

At both the Interpersonal and the Representational Level, non-core elements are placed before core elements; at the Interpersonal level, for instance, functions, operators and modifiers of the Move, Discourse Act, Illocution and Communicated Contents are placed (in that order) before any of the Subacts; while at the Representational Level, functions, operators and modifiers of the Propositional Content, Episode or State-of-Affairs are placed before the predicate and its arguments.

Finally, it is assumed that, cross-linguistically, languages make use of one or more (up to four) absolute positions for the placement of (in this case clausal) elements. English has three absolute positions: an initial $\left(\mathrm{P}^{\mathrm{I}}\right)$, a medial $\left(\mathrm{P}^{\mathrm{M}}\right)$ and a final $\left(\mathrm{P}^{\mathrm{F}}\right)$ position. As soon as one of these positions is filled, one or two relative positions are created (e.g. $\mathrm{P}^{\mathrm{M}+1}, \mathrm{P}^{\mathrm{F}-1}$ ). In addition, languages make consistent use of a preclausal and postclausal position (to accommodate what is often referred to as left and right dislocation). The following thus represents a potential template for Linguistic Expressions in English:

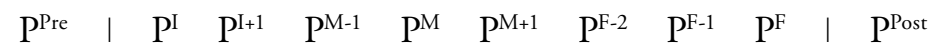

In order to illustrate how these placement rules apply, consider the following (rather contrived but grammatical) example:

${ }^{4}$ Hengeveld and Mackenzie (Functional) do not use the terms core and non-core, using the terms hierarchically related (non-core) and non-hierarchically related (core) elements instead. This, however, is confusing since some of the non-core units (e.g. the Illocution) is in fact a nonhierarchically related unit. 
As the only interpersonal modifier, the attitudinal adverb luckily (modifying the Communicated Content) is the first element to be placed in one of three absolute positions, ending up in position $\mathrm{P}^{\mathrm{M}}$. The adverb probably, as the highest representational modifier (scoping over the Propositional Content), is the next element to be placed, going to the newly created position $\mathrm{P}^{\mathrm{M}+1}$ Subsequently, the modal auxiliary will (represented as an operator at the layer of the Episode) is placed in $\mathrm{P}^{\mathrm{M}-1}$, the Episode modifier next week in clause-final position $\left(\mathrm{P}^{\mathrm{F}}\right)$, and the frequency adverb again in the pre-final position $\left(\mathrm{P}^{\mathrm{F}-1}\right)$. Finally, the main verb, subject and object and are placed in positions $\mathrm{P}^{\mathrm{M}+2}, \mathrm{P}^{\mathrm{I}}$ and $\mathrm{P}^{\mathrm{M}+3}$, respectively.

$$
\begin{aligned}
& \begin{array}{llllllll}
\mathrm{P}^{\mathrm{I}} & \mathrm{P}^{\mathrm{M}-1} & \mathrm{P}^{\mathrm{M}} & \mathrm{P}^{\mathrm{M}+1} & \mathrm{P}^{\mathrm{M}+2} & \mathrm{P}^{\mathrm{M}+3} & \mathrm{P}^{\mathrm{F}-1} & \mathrm{P}^{\mathrm{F}}
\end{array} \\
& \text { she will luckily probably meet him again next week }
\end{aligned}
$$

It will be clear that many of these placement rules agree with the general principles listed in Dik's LIPOC: for instance, within a Linguistic Expression, Clauses will typically be iconically ordered (Principle of Iconic Ordering; see Dik, The Theory I 399; Hengeveld \& Mackenzie, Functional 283-284); the Principle of Centripetal Orientation (Dik, The Theory I 401) is reflected in the fixed (and iconic) order in which auxiliaries appear in English; Dik's Principle of Domain Integrity is captured by the fact that complex constituents are first assigned a position as a whole, and tend not to be interrupted by other constituents, as well as by the fact that operators and modifiers tend to be placed next to the head (or actually the other way round in the current system) (Dik, The Theory I 402; Hengeveld \& Mackenzie, Functional 285); the Principles of Functional Stability and Pragmatic Highlighting (Dik, The Theory I 403; Hengeveld \& Mackenzie, Functional 286-287) are reflected in the fact that constituents with certain functions often appear in designated positions (e.g. Subject in $\mathrm{P}^{\mathrm{I}}$; Focus elements in $\mathrm{P}^{\mathrm{I}}$ or $\mathrm{P}^{\mathrm{F}}$ ); etc.

However, in strong contrast to this highly detailed system of linear placement of elements within a Discourse Act, very little has been said in FDG about the placement of ECCs (in the form of Subsidiary Discourse Acts) in relation to their hosts (Nuclear Discourse Acts). Before addressing this issue, let us look at ECCs in some more detail.

\section{ECCS: DEFINITION, ANALYSIS, FUNCTION}

\subsection{General characterization}

ECCs (disjuncts, parentheticals, theticals) are typically defined as non-truthconditional (non-propositional and/or syntactically non-integrated elements that are nevertheless related to an (element from) a host clause (e.g. Chafe; Quirk et al. 612-615; Espinal; Ifantidou; Fraser; Dik, The Theory I 310-311, The Theory II 381; Haegeman; Pullum \& Huddleston 575-577, Huddleston et al. 1350-1353; Potts; 
Dehé \& Kavalova; Bonami \& Godard; Heine et al. 159; Halliday \& Matthiessen 184 , see also 190-193). In many cases, the definition used also includes prosodic non-integration of the element in question (e.g. Dik, The Theory I 310-311, The Theory II 381; Haegeman 333; Pullum \& Huddleston 575-577, Huddleston et al. 1350-1353; Potts; Bonami \& Godard; Heine et al. 159; Halliday \& Matthiessen 190-193), sometimes as a necessary, defining feature (e.g. Huddleston et al. 1350; Potts). For the purposes of the present paper, I will rely on Dik's (The Theory II 381) properties of ECCs:

1. ECCs either occur on their own, or are typically set off from the clause proper by breaks or pause-like inflections in the prosodic contour; they are "bracketed off" from the clause by such prosodic features; ${ }^{5}$

2. ECCs are never essential to the internal structure of the clause with which they are associated; when they are left out, the clause still forms an integral whole;

3. ECCs are not sensitive to the grammatical rules which operate within the limits of the clause, although they may be related to the clause by rules of coreference, parallelism, and antithesis which may also characterize relations between clauses in ongoing discourse.

An additional property of ECCs mentioned by Dik (The Theory II 383; see also Heine et al. 159) is that ECCs tend to have a large degree of positional mobility: many of them may precede or follow the host, as well as interrupt the host at various places. This, of course, raises the question of what determines where a particular ECCs appears vis-à-vis the host. Before we address this question, however, let us have a look at how ECCs have been analysed in FDG.

\subsection{The analysis of ECCs IN FDG}

In FDG, the ECC status of an element is captured at the Interpersonal Level. Here, however, different types of ECC have been analysed in different ways.

${ }^{5}$ As mentioned above, in FDG this means that, generally speaking, ECCs are realized as Intonational Phrases at the Phonological Level, characterized by the presence of a complete intonational contour and boundary tones preceding and/or following the unit in question (see e.g. Crystal 205-206; Bolinger 185-189; Cruttenden 30-34; Nespor \& Vogel; Gussenhoven; Dehé, "The relation", Parentheticals). As is well-known, however, there is significant variation in the prosodic realization of ECCs, both between different types of ECC and within a particular type (e.g. Astruc; Astruc \& Nolan; Dehé, Parentheticals). Moreover, the presence or absence of a prosodic boundary need not always be communicatively motivated, and may be influenced by a range of a-functional factors, including speech rate, fluency (hesitation), (syntactic or prosodic) length/complexity (of ECC and preceding unit), and eurhythmy. For the purposes of this paper, however, it will be assumed that commas indicate intentional prosodic boundaries (which in all cases would lead to a plausible interpretation; see e.g. Astruc, Astruc \& Nolan). 
In most cases, they correspond to separate (Subsidiary) Discourse Acts; in other cases, they are analysed as modifiers of a particular interpersonal layer.

As mentioned in Section 2, Moves consist of one or more Discourse Acts. If a Move contains more than one Discourse Act, these can be related in two ways: if two Discourse Acts have equal communicative status, the relationship between them is one of equipollence; if one Discourse Act (the Nucleus) is communicatively more important than the other (a Subsidiary), the relationship between them is one of dependence. In the latter case a rhetorical function representing the relationship between the two Acts is assigned to the Subsidiary Act. Thus, in (1a), repeated here as (11a), the left-dislocated element $A$ s for the students is represented as a Subsidiary Discourse Act with the rhetorical function Orientation; in (12a) $(=(1 \mathrm{~d}))$, my brother functions as a Subsidiary Discourse Act with the function Correction (Hengeveld \& Mackenzie, Functional 55-56). Since in FDG there is a default, one-to-one relationship between Discourse Acts at the Interpersonal Level and Intonational Phrases (IPs) at the Phonological Level (Hengeveld \& Mackenzie, Functional 432; Keizer, "Interpersonal adverbs"), the two Discourse Acts in (11b) and (12b) are taken to correspond to two Intonational Phrases at the Phonological Level, as shown in (11c) and (12c).
a. As for the students, they won't be invited.
b. IL: $\left(\mathrm{M}_{\mathrm{I}}:\left[\left(\mathrm{A}_{\mathrm{I}}-\text { as for the students- }\left(\mathrm{A}_{\mathrm{I}}\right)\right)_{\text {Orient }}\left(\mathrm{A}_{\mathrm{J}}\right.\right.\right.$ : - they won't be invited- $\left.\left.\left.\left(A_{J}\right)\right)\right]\left(M_{\mathrm{T}}\right)\right)$
c. PL: $\left(\mathrm{U}_{\mathrm{i}}:\left[\left(\mathrm{IP}_{\mathrm{i}}\right)(\mathrm{IP})\right]\left(\mathrm{U}_{\mathrm{i}}\right)\right)$
a. He's a nice chap, your brother.
b. IL: $\left(M_{\mathrm{I}}:\left[\left(\mathrm{A}_{\mathrm{I}}-\right.\right.\right.$ he's a nice chap- $\left.\left.\left.\left(\mathrm{A}_{\mathrm{I}}\right)\right)\left(\mathrm{A}_{\mathrm{J}} \text { :-your brother- }\left(\mathrm{A}_{\mathrm{J}}\right)\right)_{\mathrm{Cor}}\right]\left(\mathrm{M}_{\mathrm{I}}\right)\right)$
c. PL: $\left(\mathrm{U}_{\mathrm{i}}:\left[\left(\mathrm{IP}_{\mathrm{i}}\right)\left(\mathrm{IP}_{\mathrm{j}}\right)\right]\left(\mathrm{U}_{\mathrm{i}}\right)\right)$

In some cases, however, the two Discourse Acts may be realized as three Intonational Phrases at the Phonological Level. Such a non-default relation may be communicatively motivated, as in those cases where a Nuclear Discourse Act is deliberately interrupted by a Subsidiary Discourse Act (an Aside), as in example (13), leading to the use of three separate IPs:
a. The teacher, who is not very organized, had forgotten all about it.
b. IL: $\left(M_{\mathrm{I}}:\left[\left(\mathrm{A}_{\mathrm{I}}\right.\right.\right.$ - the teacher had forgotten all about it $\left.-\left(\mathrm{A}_{\mathrm{I}}\right)\right)\left(\mathrm{A}_{\mathrm{J}}:-\right.$ the teacher is not very organized $\left.\left.\left.-\left(A_{\mathrm{J}}\right)\right)_{\text {Aside }}\right]\left(\mathrm{M}_{\mathrm{I}}\right)\right)$
c. PL: $\left(\mathrm{U}_{\mathrm{i}}:\left[\left(\mathrm{IP}_{\mathrm{i}}\right)\left(\mathrm{IP}_{\mathrm{j}}\right)\left(\mathrm{IP}_{\mathrm{k}}\right)\right]\left(\mathrm{U}_{\mathrm{i}}\right)\right)$

In FDG, vocatives are analysed as Interpellative Discourse Acts. In those cases where the vocative consists of a proper name, as in (14a), the Discourse Act has an abstract Illocution (INTERP), while the proper name functions as the head of the Addressee $\left(\mathrm{P}_{\mathrm{J}}\right)_{\mathrm{A}}$ (Hengeveld \& Mackenzie, Functional 79):
a Bert!
b. $\left(\mathrm{A}_{\mathrm{I}}:\left[\left(\mathrm{F}_{\mathrm{I}}: \operatorname{INTERP}\left(\mathrm{F}_{\mathrm{I}}\right)\right)\left(\mathrm{P}_{\mathrm{I}}\right)_{S}\left(\mathrm{P}_{\mathrm{J}}: \operatorname{Bert}\left(\mathrm{P}_{\mathrm{J}}\right)\right)_{\mathrm{A}}\right]\left(\mathrm{A}_{\mathrm{I}}\right)\right)$ 
When the vocative is in a dependency relation with another Discourse Act, e.g. Peter in (1b) (repeated here as (15)), it may be analysed as a Subsidiary Discourse Act with the rhetorical function Address (cf. Dik, The Theory I311), indicating who the Nuclear Discourse Act is directed at: ${ }^{6}$

a. I'm afraid, Peter, that you are going a bit too fast.

b. $\left(\mathrm{M}_{\mathrm{I}}:\left[\left(\mathrm{A}_{\mathrm{I}}:-\mathrm{I}\right.\right.\right.$ 'm afraid $\ldots$ too fast $\left.-\left(\mathrm{A}_{\mathrm{I}}\right)\right)\left(\mathrm{A}_{\mathrm{I}}:\left[\left(\mathrm{F}_{\mathrm{I}}: \operatorname{INTERP}\left(\mathrm{F}_{\mathrm{I}}\right)\right)\left(\mathrm{P}_{\mathrm{I}}\right)_{S}\right.\right.$ $\left.\left.\left.\left(\mathrm{P}_{\mathrm{J}}: \operatorname{Peter}\left(\mathrm{P}_{\mathrm{J}}\right)\right)_{\mathrm{A}}\right]\left(\mathrm{A}_{\mathrm{J}}\right)\right)_{\text {Addr }}\left(\mathrm{M}_{\mathrm{I}}\right)\right)$

In other cases, however, especially when the ECC takes the form of an interpersonal (non-truth-conditional) adverbial clause or phrase, FDG analyses the ECC as a modifier at the appropriate layer at the Interpersonal Level. Thus, the ECC so they say in (1c) (repeated below as (16)) would be analysed as a modifier of the Communicated Content, used by the speaker to indicate the source of the information provided (cf. Hengeveld \& Mackenzie, Functional 103; Keizer, "The interpersonal level" 856). Similarly, the adverb frankly in (17) has been analysed as a modifier of the Illocution, as it serves as a comment on the (in this case Interrogative) Illocution (meaning either "I ask you frankly why you did it" or "I ask you to tell me frankly why you did it"; Hengeveld \& Mackenzie, Functional 82).

a. John was, so they say, a bright student.

b. $\left(\mathrm{M}_{\mathrm{I}}:\left(\mathrm{A}_{\mathrm{I}}:\left[\left(\mathrm{F}_{\mathrm{I}}: \mathrm{DECL}\left(\mathrm{F}_{\mathrm{I}}\right)\right)\left(\mathrm{P}_{\mathrm{I}}\right)_{S}\left(\mathrm{P}_{\mathrm{J}}\right)_{\mathrm{A}}\left(\mathrm{C}_{\mathrm{I}}\right.\right.\right.\right.$ : - John was a bright student $\left(C_{\mathrm{I}}\right)$ : so they say $\left.\left.\left.\left.\left(\mathrm{C}_{\mathrm{I}}\right)\right)\right]\left(\mathrm{A}_{\mathrm{I}}\right)\right)\left(\mathrm{M}_{\mathrm{I}}\right)\right)$

a. Frankly, why did you do it?

b. $\quad\left(\mathrm{M}_{\mathrm{I}}:\left(\mathrm{A}_{\mathrm{I}}:\left[\left(\mathrm{F}_{\mathrm{I}}: \operatorname{INTER}\left(\mathrm{F}_{\mathrm{I}}\right)\right.\right.\right.\right.$ : frankly $\left.\left(\mathrm{F}_{\mathrm{I}}\right)\right)\left(\mathrm{P}_{\mathrm{I}}\right)_{S}\left(\mathrm{P}_{\mathrm{J}}\right)_{\mathrm{A}}\left(\mathrm{C}_{\mathrm{I}}\right.$ : - why did you do it $\left.\left.\left.\left.-\left(C_{\mathrm{T}}\right)\right)\right]\left(\mathrm{A}_{\mathrm{T}}\right)\right)\left(\mathrm{M}_{\mathrm{T}}\right)\right)$

Keizer ("Interpersonal adverbs", "The semantics"), however, argues that such an analysis should be reserved for prosodically integrated adverbials only (as these also still retain a degree of syntactic integration), ${ }^{7}$ and that prosodically nonintegrated, fully parenthetical adverbials like those in (16) and (17) are better analysed as Subsidiary Discourse Acts. We will come back to this issue in Section 5.2.

${ }^{6}$ This may seem redundant, given that the Discourse Act already has an Interpellative Illocution, with the proper name heading the Addressee. However, the Illocution and the Rhetorical function fulfil different functions: the former serves to indicate whose attention is being drawn, the latter to indicate that this is also the person the host is addressed to.

${ }^{7}$ In the sense that there are restrictions on their (absolute and relative) position, and their occurrence in the complement of verbs; moreover, in V2 languages, they still trigger inversion (Keizer, "Interpersonal adverbs", “The semantics"). 


\subsection{The FunCtions of ECCs}

From the above it will already have become clear that ECCs can fulfil different kinds of functions in the discourse (for an overview, see also Kaltenböck et al. 9-11). Dik (The Theory II 384) distinguishes four types of functions, two of which are important for the purposes of the present paper: ${ }^{8}$

1. Interactional management: greetings and vocatives (summonses, addresses) and minimal responses; Dik (The Theory II 384-386)

2. Discourse organization: boundary markers (e.g. initiators and topic shifters), Orientation markers (including Themes) and Tails (which may serve to clarify, modify, specify or correct; Dik (The Theory II 386-405)).

In their discussion of Subsidiary Discourse Acts, Hengeveld \& Mackenzie (Functional 53-58) describe some of the rhetorical functions these Acts can have. In example (18a) we are dealing with a case of Motivation, as the Subsidiary Discourse Act provides the speaker's motivation for uttering the Nuclear Discourse Act; example (18b) provides an example of Orientation (Dik's Theme; see also example (11)); in (18c) we have a Discourse Act with the function of Correction (see also example (12)); in (18d), the Subsidiary Discourse Act has the rhetorical function of Concession (as shown by the possibility of adding a performative); and (18e) contains an Aside (see also example (13)):

(18) a. Watch out, because there will be trick questions in the exam.

b. My brother, I promise not to betray him.

c. I promise not to betray him, my brother.

d. The work was fairly easy, although (I concede that) it took me longer than expected.

e. The students, who, frankly, had worked hard, passed the exam. (examples from Hengeveld \& Mackenzie, Functional 53-58)

Hannay \& Keizer also analyse non-restrictive nominal appositions, such as those given in (19)-(21), as separate Discourse Acts provided with a function capturing their specific discourse (rhetorical) function. These functions come in three major groups (cf. Quirk et al. 1308-1313). The first is that of identification, which applies to those cases where the non-restrictive apposition is intended "to enable the hearer to identify the referent of the host, not necessarily uniquely, but sufficiently for the current discourse purpose" (Hannay \& Keizer 169); it may take the form of specification, description or reformulation. An example of specification is given in (19):

8 The other two types distinguished by Dik are attitude specification (Ouch!, Dammit!, Hurray!; Dik, The Theory II 386) and discourse execution (responses and tags; The Theory II 405-407). 

Trump could be a "moment of opportunity" for a fresh start. (COCA, newspaper)

The second major category of discourse function is that of justification; appositions with this function are meant to forestall the question "Why is this relevant?" (Hannay \& Keizer 173). One subtype of justification is reference justification, as the apposition serves "to justify the speaker's referring to a particular person at that particular moment" (Hannay \& Keizer 175), as in example (20):

(20) Last year, Peter Tatchell, the gay rights activist, invaded the stage to give an impromptu address. (York Minster invaded by angry fathers, The Guardian, 12 July 2004)

The third major category is that of labelling, i.e. those cases where a new label (typically a proper name) is attached to an unfamiliar discourse entity, as in (21):

(21) But Mr Hobson's mother and his ex-wife, Kay, had pleaded with him to give himself up. (Hunt ends for most wanted man, The Guardian, 26 July 2004)

As pointed out by Dik (The Theory II 383), there may be a relation between the specific discourse or rhetorical function of an ECC and its preferred position (e.g. in the case of Themes and Tails); in other cases, however, an ECC "may occur, with much the same function" in virtually any position (Dik, The Theory II 383). In the next section we will consider some of the factors that determine where an ECC eventually appears.

\section{THE PLACEMENT OF ECCS}

\subsection{INTRODUCTION}

As mentioned before, one generally accepted feature of ECCs is that they are positionally mobile (e.g. Dik, The Theory I 311, The Theory II 379, 383; Heine et al. 159). This does not mean, however, that placement is entirely free or arbitrary: in many cases, there clearly is a link between the discourse-pragmatic or rhetorical function of the ECC and its position vis-à-vis its host. Thus, Subsidiary Discourse Acts with the function Orientation/Theme tend to end up in preclausal position (e.g. The Theory II 388), while those serving as Tails of Afterthoughts appear in postclausal position (Dik, The Theory II 403). In many cases, however, rhetorical function alone is not enough to predict position: vocatives, such as Peter in (1b), may 
end up in preclausal, postclausal and interpolated ${ }^{9}$ position (Dik, The Theory II385), while Motivations may occur in preclausal and postclausal position (Hengeveld \& Mackenzie, Functional 54). Furthermore, as is well-known, non-restrictive relative clauses, although typically immediately following their antecedent (as in example (13)), may, for a variety of reasons, be placed in postclausal position (see discussion in Section 5.2).

Similarly, prosodically non-integrated adverbs can occur in a whole range of positions, as shown in example (22) for the illocutionary adverb frankly:

(22) a. Frankly, I don't think they keep Obamacare. (COCA, spoken)

b. And, frankly, last night was one of the big nights. (COCA, spoken)

c. You, frankly, are a bit of a slut. (BYU-BNC, pop-lore)

d. In those kind of cases, frankly, it's the person who is making statements with a lot to lose (COCA, spoken)

e. I would say, on balance, frankly, the mainstream press, which is decried often by conservative as liberal, is more professional and more accurate and faster to correct mistakes than probably it was in an earlier era. (COCA, spoken)

f. It has, frankly, all been downhill for House Tyrell since then (COCA, magazine)

g. And he covered, frankly, a lot of ground when he was in that briefing room (COCA, spoken)

h. And I'd like to take it to that place because, frankly, the place where the Republicans are going now with their budget is a very bad place for our country. (COCA, spoken)

i. I think that's a question, frankly, you'd have to ask the Democrats (COCA, newspaper)

j. and I'd never, frankly, thought about it before, because I never knew anybody intimately in the business world (COCA, spoken)

k. And so, we have seen this for decades, for years, quite frankly. (COCA, spoken)

Finally, corrections, as cases of self-monitoring, can occur in almost any position (Dik, The Theory II 402; Geluyckens 122-124; see also Hengeveld \& Mackenzie, Functional 55-56):

a. But we already have a pa, or rather we had one. (COCA, fiction)

9 This term was introduced by Keizer ("Interpersonal adverbs" 82) for Subsidiary Discourse Acts interrupting their host (to be distinguished from the term medial, used for Discourse Act internal elements). 
b. But, as I understand it, the reason that your parents were sent back - or rather that your dad was - was that they say he participated in helping to destroy a mosque, (COCA, spoken)

c. I always say, once the year turns even, that is, an election year, you are less likely to see any major legislative accomplishments (COCA, spoken)

From this very brief overview, it will be clear that the placement of ECCs is determined by a number of interacting factors, including the following: ${ }^{10}$

- processing factors (planned vs. unplanned ECCs; complexity)

- rhetorical function (relation to the host)

- targeting (relation to particular unit within the host)

- information structure (strengthening or weakening of the backgrounded status of the ECC; pragmatic function (topic/focus/contrast) of the ECC or (elements of) the host)

In what follows, we will look at a number of corpus examples illustrating the different types of ECCs mentioned so far (orientational noun phrases, vocatives, motivational if-clauses, non-restrictive relative clauses and appositions, and reportative adverbials), to try and answer the following questions: how can the interplay between these factors be captured in FDG?; and how can the placement of ECCs be integrated in the placement rules of FDG?

\subsection{The placement of planned Subsidiary Discourse Acts 5.2.1. Orientational ECCs}

Let us start with those ECCs which, due to their specific discourse function, can be assumed to be deliberately placed in a particular position. These include those elements that, for communicative purposes, are placed in preclausal position, such as elements with the rhetorical function Orientation (including what Dik (The Theory II 385) classifies as Addresses). Their preclausal position also indicates the fact that they have wide scope: they pertain to the following Discourse Act as a whole. Sometimes, as in example (24a), their function is purely discourse-organizational: they serve to draw attention to the particular (discourse relevant) piece of information (participant or topic) that the following clause (representing the Nuclear Discourse Act) is about. These participants may be discourse-new (Prince, "The ZPG letter"), as in examples (24a) and (24b); note, however, that they are nevertheless to some degree hearer-old (familiar, inferrable; Prince "Toward a taxonomy", "The ZPG letter"), in that they are either related to (e.g. examples (24a) and (24b)) or evoke

${ }^{10}$ For a similar approach to the placement of 'thematic parentheticals', see Hannay \& Gómez González. 
(example (24c)) a previously mentioned discourse participant. In other cases the orientational Subact is resumptive (example (24d)), in which case it can be used to signal a shift in discourse topic. Note that in all these cases, the orientational Subact functions as a link between the previous and the following discourse, i.e. as a coherence enhancing device (Dik, The Theory II 388).

(24) a. I am the classic example of a passive-aggressive kind of guy. And it's amazing. I'm sitting here. Let me tell you what happened. My girlfriend, she's so upset with me. We're in the middle of a big, huge argument right now. (COCA, spoken)

b. My daughter, Leila, who is eighteen, she came home all excited. (COCA, spoken)

c. We're not married, but she and I have been together for seven years now, and we have a wonderful son - awesome kid, man. The complete opposite of what I was his age - happy. My son, he looked at me one day when I yelled at him. He shook. Oh, my God, that was me. (COCA, spoken)

d. In addition to intervention in production, the other two pillars of Wang's policies were inflationary monetary policy and permanent war. Wang seized control of copper output, quadrupling the issue of bronze coin (von Glahn 2005, 71), which set off rising inflation. As for military adventures, during his short tenure Wang managed to initiate wars against a series of regional powers simultaneously, including the Ly dynasty in modern Vietnam, and his followers frequently returned to the theme of war. (COCA, academic)

In many instances, however, orientational Discourse Acts also carry pragmatic information, as in the following examples, where they serve to indicate contrast between the referent introduced by the orientational Discourse Act and another, previously introduced discourse referent. This particular combination of orientation and contrast triggers prosodic prominence on the orientational element (Kumail's parents vs. Emily's parents in (25a); the (un)insured vs. the insurers in (25b)):

(25) a. Not that what Kumail's parents did was not good parenting. But my parents - I've always been a little bit more with them, ... (COCA, spoken)

b. they argued that the individual mandate is the "heart" of the healthcare law, and without it, both the number of uninsured Americans and premiums would skyrocket (...). \# And many conservative health policy experts agree repealing only the individual mandate is a crummy idea. \# "Having guaranteed issue and community rating without some sort of mandate is structurally a rather dangerous thing to do," Robert Graboyes, a health-care scholar at the Mercatus Center. "It's an invitation to a death spiral." \# As for insurers, they're terrified that Republicans are considering "skinny repeal" as a possibility. (COCA, newspaper) 
The placement of these Subsidiary Discourse Acts vis-à-vis their hosts is quite straightforward: they are simply put in preclausal position before any of the constituent parts of the Nuclear Discourse Act is placed in position. For example (25a) this would lead to the (simplified) representation at the Interpersonal Level (26a) and template at the Morphosyntactic Level (26b):

$$
\begin{aligned}
& \text { a. } \left.\left(\mathrm{M}_{\mathrm{I}}: \quad \ldots \quad\left[\left(\mathrm{A}_{\mathrm{I}}-\mathrm{my}_{\text {CONTR }} \text { parents }-\left(\mathrm{A}_{\mathrm{I}}\right)\right)_{\text {Orient }}\left(\mathrm{A}_{\mathrm{J}}\right)\right)\right] \ldots\left(\mathrm{M}_{\mathrm{I}}\right)\right) \\
& \text { b. } \begin{array}{lllllll}
\text { Pre } & \text { । } & \mathrm{P}^{\mathrm{I}} & \mathrm{P}^{\mathrm{M}-1} & \mathrm{P}^{\mathrm{M}} & \mathrm{P}^{\mathrm{M}+1} & \mathrm{P}^{\mathrm{M}+2}
\end{array} \\
& \text { my parents }
\end{aligned}
$$

\subsubsection{Vocatives}

Not surprisingly, vocatives can also occur in preclausal position. Here they may be used to start a new discourse, as in example (27a) (Dik, The Theory II 387 ), or they may constitute an attempt on the part of the speaker either to draw the attention of a particular discourse participant, as in (27b) (Dik's (The Theory II 385) Addresses; cf. Leech's $(108,116)$ attention drawing function), or to draw other speech participants' attention to a particular speech participant, as in (27c), where the use of the proper name Nancy is as much for the benefit of the audience (listeners) as for the addressee herself:

a. Dear friends, I am pleased to get in touch with you through Twitter. (COCA, magazine)

b. (SP:PS052) Wait a minute, don't touch the knife. I'll move the sandwiches. Andrew, will you leave it please. Don't interfere.

c. DICKERSON\# And we're back with more from our CBS correspondent round table. Nancy, I want to start with you, picking up on the point that Jan was making about what Democrats are going to do to resist the -- Mr. Trump's picks.

In these preclausal positions, the use of a vocative is clearly planned, i.e. conceptualized (in the Conceptual Component) and evoked (in the grammar, at the Interpersonal Level) together with their host. This may also be true for vocatives in later positions, as towards the end of the passage in (28a), where the vocative is used in indicate a change in addressee (from Kevin to Ron). Deliberate uses of a vocative can also be found in (28b), where the use of a title to explicitly address the hearer may be regarded as an expression of politeness (since the addressee is fully identifiable; cf. Leech's (111) honorifics). In addition, the particular placement of the vocative in both (28a) and (28b) may be inspired by a wish to separate the topical (or rather background) information from the focal (most salient) information (see Hengeveld \& Mackenzie, Functional 89-92):

(28) a. (Nichols:) Now Kevin, you're joining us from Washington, and we will start with you. Do you think people even understand what the Redskins' 
name means? KEVIN-GOVER, -DIREC\# more and more people are beginning to understand. You know, it's always been a frustration of mine that we couldn't seem to be a part of the public discourse and get people to listen and focus. Because once you do listen and focus, the answers become very clear that this is not a word that should be used NICHOLS\# Yes. You talked a little bit, Ron, about your own family history and how that plays into the way you see this issue. (COCA, spoken)

b. There have been a lot of questions, Doctor, about family members trying to reach their loved ones, (COCA, spoken)

In addition, vocatives can be placed deliberately in postclausal position, as a way of emphasizing, or more specifically confirming (often in a way expressing some annoyance or exasperation), who it is that the message is intended for (as in examples (29a) and (29b)), thus combining a rhetorical function (vocative) with a pragmatic one (emphasis). Despite their postclausal position, these vocatives may be assumed to be planned by the speaker, in which case they may be analysed as Subsidiary Discourse Acts with the function Addressee (see above). The specific interactional function of the vocative may be captured by adding an operator ('conf' for confirmation) to the Addressee Speech Participant in the Subsidiary Discourse Act. In that case, it would be the presence of this operator, in combination with the interpellative nature of the ECC, that triggers the postclausal position (as illustrated in (30) for example in (29b)).

a. I also said every morning you went to work you were terrified, Bobby. (BYU-BNC, conversation)

b. Well, somebody has to do that work, Steve. (COCA, spoken)

$\left(\mathrm{A}_{\mathrm{I}}:\left[\left(\mathrm{F}_{\mathrm{I}}: \operatorname{DECL}\left(\mathrm{F}_{\mathrm{T}}\right):\left(\mathrm{P}_{\mathrm{I}}\right)_{S}\left(\mathrm{P}_{\mathrm{J}}\right)_{\mathrm{A}}\left(\mathrm{C}_{\mathrm{I}}:-\right.\right.\right.\right.$ somebody $\ldots$ work $\left.\left.\left.-\left(\mathrm{C}_{\mathrm{I}}\right)\right)\right]\left(\mathrm{A}_{\mathrm{I}}\right)\right)\left(\mathrm{A}_{\mathrm{J}}\right.$ : $\left.\left[\left(\mathrm{F}_{\mathrm{I}}: \operatorname{INTERP}\left(\mathrm{F}_{\mathrm{I}}\right)\right)\left(\mathrm{P}_{\mathrm{I}}\right)_{\mathrm{S}}\left(\operatorname{conf} \mathrm{P}_{\mathrm{J}}: \text { Steve }\left(\mathrm{P}_{\mathrm{J}}\right)\right)_{\mathrm{A}}\right]\left(\mathrm{A}_{\mathrm{J}}\right)\right)_{\text {Addr }}$

In sum, the position of vocative ECCs seems to be determined by a combination of factors. First of all, there is the fact that these expressions are used as vocatives, i.e. attention-drawing devices (e.g. examples in (27)). Secondly, there is the discourse-organizational element of task urgency: when does the speaker find it necessary or expedient to explicitly mention the addressee (e.g. examples in (28)). And thirdly, there are pragmatic factors involved, as in (28a) and (28b)), where the vocative separates the focal from the background information, and in (29), where the final position is triggered by the wish to confirm the identity of the addressee (which may then trigger further implicatures on the part of the hearer).

So how can the placement of (at least some of) these vocatives be accounted for in FDG? Clearly, the combination of an interpellative Discourse Act with the rhetorical function of Address favours the preclausal position, especially at the beginning of a conversation, or at a point in an ongoing discourse where a different participant is being addressed. Especially in the latter case, an interpolated position is also possible. Consider the following example: 
KING: It had to be horrific for you GARDNER: It really didn't sink in KING: Really? GARDNER: It really hadn't sunk in that something was critically wrong with him. You know, we've had situations like this, where there's been small bites or small injuries before, and it has never been a -- you know, a big deal until -- I didn't realize that it was as big a deal as it was until later KING All right, Jack Hanna, how dangerous is that? Have you ever seen, Jack, the Siegfried \& Roy show? JACK HANNA, DIR. EMERITUS, COLUMBUS ZOO: Well, I've seen the show several times (COCA, spoken)

This passage is interesting because in the final part it contains two vocatives in two consecutive sentences, both addressing the same person. The first, using the full name of the addressee, Jack Hanna, is used to indicate, presumably for the sake of the audience, a shift in addressee. This vocative appears, quite predictably, in preclausal position (following another preclausal element, all right). In the next sentence, however, another vocative is used to address the same person, now in the form of the first name only (Jack). This vocative does not occur in preclausal position; after all, both the speech participant in question and the other speech participants, including the listeners, already know who is being addressed. Instead, the vocative interrupts the host, occurring between the predicate and the direct object. Its particular position may have been chosen for discourse-pragmatic reasons. Notice that the pronoun you carries some degree of contrastive prominence here, as the speaker is moving from one interviewee (clearly involved in the show in question, the Siegfried \& Roy show), to another, who may never have seen it. The vocative may thus be intended to more clearly bring out the contrast, while at the same time serving to separate the focal from the backgrounded information.

Let us now focus on the second italicized sentence, repeated in (32). Here we clearly have two Discourse Acts, each with their own lllocution (Interrogative and Interpellative). The Interpellative Act can be regarded as subsidiary, as it merely functions as a reminder of who is being addressed.

a. Have you ever seen, Jack, the Siegfried \& Roy show?

b. $\left(\mathrm{A}_{\mathrm{I}}\right.$ : $\left[\left(\mathrm{F}_{\mathrm{I}}: \operatorname{INTER}\left(\mathrm{F}_{\mathrm{I}}\right):\left(\mathrm{P}_{\mathrm{I}}\right)_{\mathrm{S}}\left(\mathrm{P}_{\mathrm{I}}\right)_{\mathrm{A}}\left(\mathrm{C}_{\mathrm{I}}:-\right.\right.\right.$ have you ... show $\left.\left.\left.-\left(\mathrm{C}_{\mathrm{I}}\right)\right)\right]\left(\mathrm{A}_{\mathrm{I}}\right)\right)$ $\left(A_{\mathrm{J}}:\left[\left(\mathrm{F}_{\mathrm{I}}: \operatorname{INTERP}\left(\mathrm{F}_{\mathrm{I}}\right)\right)\left(\mathrm{P}_{\mathrm{I}}\right)_{S}\left(\mathrm{P}_{\mathrm{J}} \text { : Jack }\left(\mathrm{P}_{\mathrm{J}}\right)\right)_{\mathrm{A}}\right]\left(\mathrm{A}_{\mathrm{J}}\right)\right)_{\text {Addr }}$

Application of the placement rules of FDG would lead to the morphosyntactic template given in (32). Tense, an episodical operator, is the highest non-core element, and is placed in $\mathrm{P}^{\mathrm{I}}$ (given that we have an Interrogative Illocution), where it is joined by the auxiliary have (expressing an operator at the layer of the SoA). The frequency adverb ever, modifying the SoA, is placed in $\mathrm{P}^{\mathrm{M}}$. Of the core units, the subject you is placed first, as it has a pragmatic function (Contrast) (see Keizer, A Functional 200 ); this element goes to $\mathrm{P}^{\mathrm{M}-1}$. Finally, the predicate is placed in $\mathrm{P}^{\mathrm{M}+1}$, and the Undergoer argument in $\mathrm{P}^{\mathrm{M}+2}$.

$$
\begin{aligned}
& \begin{array}{llllllll}
\mathrm{P}^{\mathrm{I}} & \mathrm{P}^{\mathrm{M}-1} & \mathrm{P}^{\mathrm{M}} & \mathrm{P}^{\mathrm{M}+1} & \text { | } & \mathrm{P}^{\mathrm{Int}} & \text { | } & \mathrm{P}^{\mathrm{M}+2}
\end{array} \\
& \text { have you ever seen Jack the Siegfried \& Roy show }
\end{aligned}
$$


As a separate Discourse Act, the vocative is not part of the clausal template; instead it will be assigned an interpolated position, which, like the preclausal and postclausal position, is extra-clausal. ${ }^{11}$ In this case, its particular position between $\mathrm{P}^{\mathrm{M}+1}$ and $\mathrm{P}^{\mathrm{M}+2}$ is determined by a combination of factors: a lack of urgency in identifying the addressee (ruling out the preclausal position), the desire to bring out the contrast between the addressee and the other interviewee (preferring a position following the contrastive element you), and the wish to separate focal from background information.

\subsubsection{Motivational if-clauses}

As mentioned before, Subsidiary Discourse Acts with the rhetorical function of Motivation can occur in preclausal and postclausal position. Examples are given in (34), where the position of the Subsidiary Discourse Act determines the form of the conjunction (because in (34a), so in (34b); examples from Hengeveld \& Mackenzie (Functional 54)):

a. Watch out, because there will be trick questions in the exam.

b. There will be trick questions in the example, so watch out.

In the choice between the two positions context plays a crucial role. Consider the following two examples with a motivational Subsidiary Discourse Act introduced by the conjunction if:

a. Tom opened the front door and said pleasantly, "Hullo! So you both found your way here after all." \# "Time has not blunted your acute powers of observation Tommy," said McCrimmon strolling in with the teacher behind him. \# "Drop your coats in there," said Tom pointing to a bedroom. "If you're hungry there's plenty to eat in the kitchen but I'm afraid the booze is running out." \# "I've heard that one before," said McCrimmon grimly. (COCA, fiction)

b. \# Marty let out a relieved sigh, and I turned to walk away. \# "Wait!" Marty jumped in front of me." You've got a pretty good eye for magic. If you're interested, I have an idea." \# That's how the Magic Marty and Mysterious Matt Lunch Show began. \# (COCA, fiction)

c. "... Buying a candy bar 50 years ago was a rare treat, now it's something you can buy whenever you want," he says. "Ifyou're hungry for ice cream,

11 Other important issues that have not yet been addressed in FDG is the exact nature of these extra-clausal positions and their status within the larger Linguistic Expression. Answering these questions, however, requires further research into the placement of elements within the Linguistic Expression; this cannot be dealt with within the scope of the present paper. 
a "You rest," she said to Peter Elroy. "That sofa reclines, ifyou're interested." She had not mentioned his diagnosis, and he knew that she wouldn't. (COCA, fiction)

b. "Snow's supposed to go all night and all day tomorrow. There's a hotel just down the street, left on Main. Good caf close by, too, Frumpy Joe's, if you're hungry. The Roadhouse is a bit of a walk, but it has great chowder." (COCA, fiction)

c. She sorted through the papers and pushed across some stapled xerox sheets. Sugar grains crunched and gritted on the table beneath it. "This is a report on the $\mathrm{PhD}$ work he did, ifyou're interested. I had it copied from a microfilm of the Journal of Comparative and Physiological Psychology for 1975. It's a pretty poor piece of research." (COCA, fiction)

In all these examples the if-clauses are clearly interpersonal: they do not express a condition that needs to be fulfilled for the event described in host to take place, but are used by the speaker to explicitly state her reason for uttering the host (i.e. the Nuclear Discourse Act). What determines whether the motivation precedes or follows the host is the information status of (elements of) the host. ${ }^{12}$ Thus, in example (35), where the if-clauses appear in preclausal position, they tend to mark a shift in topic (examples (35a) and (35b)) or indicate contrast with the topic of preceding discourse (example (35c)). This particular function of the preclausal if-clause seems to be further reinforced by the presence of certain degree of prosodic prominence. In the examples in (36), on the other hand, the if-clauses are not used to indicate a change in discourse topic (note, for instance the use of too in the host in (35b), and the mention of another place to eat after the if-clause). As a consequence, the Subsidiary Discourse Act is much more backgrounded, so as not to interrupt the flow of the discourse.

\subsubsection{Non-restrictive relative clauses}

So far, we have been dealing with ECCs that comment on the host as a whole. We will now consider a number of ECCs that clearly target a particular unit within the host, starting with non-restrictive relative clauses. As is well known, nonrestrictive relative clauses tend to interrupt their host, in which case they typically follow the target (Huddleston et al.'s (1351) 'anchor'). In these cases, the position of the non-restrictive relative clause, analysed as a Subsidiary Discourse Act with

12 That is, in those cases where the postclausal if-clause is planned. They may, of course, also appear as afterthoughts (see Section 5.3). 
the rhetorical function Aside, is clearly motivated, as it immediately follows the element from the host they comment on (see also Huddleston et al. 1351; Potts 104; Blakemore 1685):

CEO Steve Penny, who was returning home from a pre-Olympic visit to Rio de Janeiro, spoke with an unidentified athlete's mother days later. (COCA, newspaper)

Occasionally, however, non-restrictive relative clauses functioning as Asides are separated from their target and placed in postclausal position. The placement of these clauses is, once again, not random. One obvious reason for placing the nonrestrictive relative clause in final position is complexity (principle of end weight; e.g. Quirk et al. 323, 1282ff; Biber et al. 898; Dik, The Theory I 404); this is illustrated in the following examples, where placing the non-restrictive clause in postclausal position facilitates processing by the hearer (as well as, presumably, production by the speaker).

(38) a. But the funniest sentence I know, which a certain actor from the Hungarian Regional Theater taught me, whose name was Btori and who was from Btorove Kosihy, is: ... (COCA, fiction)

b. Israel police said they arrested a 17-year old minor on Nov. 8, who was from the settlement of Itamar and confessed to the attack. (COCA, newspaper)

Discourse factors, however, may also play an important role. Thus, in some cases the non-restrictive relative clause may actually move the discourse forward, by providing new, salient information; in those cases, the backgrounding function normally associated with non-restrictive clauses is weakened, with the non-restrictive relative clause serving more or less as a main clause (e.g. Hannay \& Mackenzie 112-113). An example is given in (39), where the non-restrictive relative clause in final position not only elaborates on the information given in the previous clause, by adding new information about one of the participants (thousands of ostensibly Palestinian protesters), but in addition provides the link between the previous clause and the following one, thus lending coherence to the passage:

(39) While struggling to remain in power, the Assad regime in Syria sought to divert public anger against it by busing thousands of ostensibly Palestinian protesters to the Israeli border, who then proceeded to try to cross into the Jewish state. Jerusalem will find it necessary to station larger forces along its frontiers to defend against an array of security threats arising from the turmoil in neighboring states (COCA, academic)

Formally, however, we are still dealing with a subordinated clause, which means that in FDG they will be analysed as Subsidiary Discourse Acts. It is the 
particular Rhetorical function of this Act (I suggest Elaboration) which triggers placement in postclausal position.

\subsubsection{Non-restrictive appositions}

In many ways, non-restrictive nominal appositions behave in the same way as non-restrictive clauses. They typically follow their target (example (40); see also examples (19)-(21) above)), but may be placed in postclausal position if they are complex (example (41)). Assuming that in both cases the presence of the Subsidiary Discourse Act was planned, they will be analysed as Asides. As in the case of nonrestrictive relative clauses, however, they may also have an elaborating, coherence enhancing function, as in example (42).

(40) a. And when David heard it, he loaned it to Alex, my brother, saying, you might like this record. (COCA, spoken)

b. Dr. David Lattimore, a physician, had administered the first smallpox vaccinations in the Mississippi Territory. (COCA, academic)

(41) a. at about the same time a new figure appeared on the scene, the 39-yearold Edward Dumouriez, an able army officer who had canght the eye of the king and been appointed Commandant of Cherbourg. (BYU-BNC, fiction)

b. Charlie appeared almost immediately, a tall, lanky youth, looking younger on the surface than the autopsy would later place him. (BYU-BNC, fiction)

(42) a. I never had a chance to talk. Here I was, this hotshot coach. The girls made you humble right away. (COCA, magazine)

b. She says you came and picked him up that same day and took him away. Is that true?" \# "I thought I knew better how to take care of my own son than she did, a stranger." \# "I thought you said she was a friend. Why would you leave your injured son with a stranger?" (COCA, fiction)

In addition, however, nominal appositions in postclausal position may have the kind of emphasizing, confirming function identified for vocatives above, though this time the effect is typically a positive one (expressing endearment). Here the apposition, typically definite, does not provide any additional, identifying or descriptive information; the target is, in all cases, fully identifiable.

(43) a. You look exactly like him. He was a very handsome man, your father. (COCA, fiction)

b. He's a good hand with cattle, your boy. (COCA, fiction)

c. She is a devil, this one. (COCA, fiction) 


\subsubsection{Reportative adverbials}

Finally, let us have a closer look at those ECCs that have been analysed as interpersonal modifiers in FDG. As we have seen, these may interrupt the host in various places, as shown for the reportative modifier so they say in the following examples, where the modifier seems to precede its target:

a. John was, so they say, a bright student (= (1c), (16a)).

b. The caravan, so they say, is bound for Jerusalem. (COCA, fiction)

c. Someday, so they say, for each of us there will be no money, no sensation. (COCA, fiction)

d. It's been happening, so they say, for millions of years. (COCA, magazine)

Application of the FDG placement rules, however, may prove to be problematic. Consider the following example: ${ }^{13}$

John had frequently, so they say, insulted her.

According to the placement rules, the reportative modifier, as a non-core, interpersonal element, would be the first element to be assigned a position, which would have to be the clause-medial position. The next non-core element would be the tense operator, specifying the Episode at the Representational Level (expressed on the auxiliary have, expressing an SoA operator). There is, however, no clausal position available for this element: it can neither go to the absolute position $\mathrm{P}^{\mathrm{I}}$ (since it does not occur in initial position), nor to the relative position $\mathrm{P}^{\mathrm{M}+1}$, as this is taken by the (yet to be placed) aspectual adverb frequently. The only possibility is, therefore, to assume that the modifier goes to a non-clausal, interpolated position:

$\begin{array}{lllllll}\mathrm{P}^{\mathrm{I}} & \mathrm{P}^{\mathrm{M}} & \mathrm{P}^{\mathrm{M}+1} & \mathrm{P}^{\mathrm{Int}} & \mathrm{P}^{\mathrm{M}+2} & \mathrm{P}^{\mathrm{M}+3} \\ \text { John } & \text { had } & \text { frequently } & \text { so they say } & \text { insulted } & \text { her }\end{array}$

This, however, raises the question of how this interpolated position, and the corresponding prosodic non-integration, is triggered. Clearly it cannot be triggered by the interpersonal status of the modifier, since (i) interpersonal modifiers need not be realized as ECCs; $;{ }^{14}$ and (ii) representational modifiers can also be realized as ECCs. It is, therefore, more plausible to analyse these modifiers as separate Subsidiary Discourse Acts with the rhetorical function Aside, just like the ECCs discussed above (see also Keizer, "Interpersonal adverbs", "The semantics"). This Subsidiary

${ }_{13}$ Note that we would encounter the same problem in example (44d), assuming that the for-PP takes a clausal (rather than a postclausal) position.

${ }^{14}$ In which case they are assigned a (more restricted) clausal position and the placement rules apply. 
Discourse Act has its own Illocution (declarative), and its own Communicated Content (so they say):

$$
\begin{aligned}
& \left(\mathrm{A}_{\mathrm{I}}:\left[\left(\mathrm{F}_{\mathrm{I}}: \operatorname{DECL}\left(\mathrm{F}_{\mathrm{I}}\right)\right):\left(\mathrm{P}_{\mathrm{I}}\right)_{S}\left(\mathrm{P}_{\mathrm{J}}\right)_{\mathrm{A}}\left(\mathrm{C}_{\mathrm{I}}:-\mathrm{John}\right. \text { had frequently insulted her- }\right.\right. \\
& \left.\left.\left.\left(\mathrm{C}_{\mathrm{I}}\right)\right)\right]\left(\mathrm{A}_{\mathrm{I}}\right)\right)\left(\mathrm{A}_{\mathrm{J}}:\left[\left(\mathrm{F}_{\mathrm{J}}: \operatorname{DECL}\left(\mathrm{F}_{\mathrm{J}}\right)\right)\left(\mathrm{P}_{\mathrm{I}}\right)_{S}\left(\mathrm{P}_{\mathrm{J}}\right)_{\mathrm{A}}\left(\mathrm{C}_{\mathrm{J}}: \text { so they say }\left(\mathrm{C}_{\mathrm{J}}\right)\right)\right]\left(\mathrm{A}_{\mathrm{J}}\right)\right)_{\text {Aside }}
\end{aligned}
$$

Naturally, this analysis would then also have to be assumed for other prosodically non-integrated (interpersonal or representational) modifiers, such as the illocutionary adverb frankly, which, as shown in example (22) above, is highly mobile. Here, too, it can be assumed that, when interrupting the host, frankly targets a particular part of the host; in this case, however, the ECC tends to follow its target. Consider example (48a). Here frankly fulfils one of its more specific discoursepragmatic functions, namely that of admitting something unpleasant, unusual or unexpected (cf. Fraser 168; Halliday \& Matthiessen 192-193). In addition it targets the adverb never, thereby reinforcing the unexpectedness of the message conveyed in the host. In (48b), frankly clearly targets the contrastive (prosodically prominent element) element you, while at the same time separating the topical information (the addressee) from the focal information (being a bit of a slut). Note that in any other position, the particular contribution of the adverb frankly to the discourse would be different.

a. and I'd never, frankly, thought about it before, (COCA, spoken)

b. What she is saying, with her big white collars, is, "I am a clean, controlled and decent Christian woman. I believe in marriage and the family. And smacking. You, frankly, are a bit of a slut." (BYU-BNC, pop-lore)

Note that here, too, the clausal placement rules cannot be applied; as in the case of so you say, we have to assume an interpolated position which is not part of the clausal template, ${ }^{15}$ and which is triggered by the Subsidiary Discourse Status of the adverb, its particular position determined by the specific element it targets in the Nuclear Discourse Act. Thus the Interpersonal Level analysis for example (48a), given in (49), would trigger the morphosyntactic template in (50):

$\left(\mathrm{A}_{\mathrm{I}}:\left[\left(\mathrm{F}_{\mathrm{I}}: \operatorname{DECL}\left(\mathrm{F}_{\mathrm{I}}\right):\left(\mathrm{P}_{\mathrm{I}}\right)_{\mathrm{S}}\left(\mathrm{P}_{\mathrm{J}}\right)_{\mathrm{A}}\left(\mathrm{C}_{\mathrm{I}}:-\mathrm{I}\right.\right.\right.\right.$ 'd never thought about it before $\left.\left.\left.\left(\mathrm{C}_{\mathrm{I}}\right)\right)\right]\left(\mathrm{A}_{\mathrm{I}}\right)\right)\left(\mathrm{A}_{\mathrm{J}}:\left[\left(\mathrm{F}_{\mathrm{I}}: \operatorname{DECL}\left(\mathrm{F}_{\mathrm{I}}\right) \text { : frankly }\left(\mathrm{F}_{\mathrm{I}}\right)\right)\left(\mathrm{P}_{\mathrm{I}}\right)_{\mathrm{S}}\left(\mathrm{P}_{\mathrm{J}}\right)\right]\left(\mathrm{A}_{\mathrm{J}}\right)\right)_{\text {Aside }}$

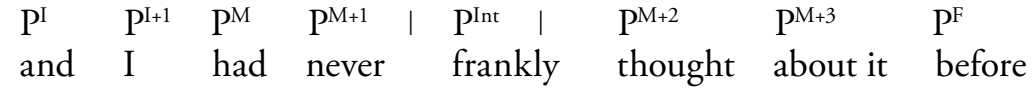

${ }_{15}$ According to the placement rules, the element and would be placed first, in $\mathrm{P}^{\mathrm{I}}$, followed by the interpersonal adverb frankly, which can only go to $\mathrm{P}^{\mathrm{M}}$. This would again lead to problems in the placement of the next element, tense, given the fact that its placement depends on the placement of the aspectual adverb never, which has not yet been assigned a position. 


\subsection{The placement of unplanned Subsidiary Discourse Acts}

So far, we have been looking at planned ECCs, i.e. Subsidiary Discourse Acts that are conceptualized (in the Conceptual Component) and evoked (in the grammar, at the Interpersonal Level) together with their host. Morphosyntactically, the two Discourse Acts were analysed as part of a single template for the Linguistic Expression, with the ECC appearing in an extra-clausal (preclausal, postclausal or interpolated) position. Such an analysis is clearly not appropriate for unplanned ECCs, which are only evoked in the course of, or after, the production of the host. Their position, interrupting or following the host, is determined, in an online fashion, during the Articulation of the Nuclear Discourse Act.

The clearest cases of unplanned ECCs are corrections (or, more generally, self-repair, cf. Levelt). These occur as a result of the speaker's self-monitoring, either immediately following the relevant (incorrect) part of the host, or at some later stage (but typically within the same turn; e.g. Schegloff et al.), and are often explicitly introduced by such markers as or rather, I mean, I'm sorry etc. (see example (51)).
a. Also yesterday, or rather Thursday, what we had going on was oil. (COCA, spoken)
b. So I just want to reassure the viewer, I mean the caller, that I'm feeling OK right now. (COCA, spoken)
c. the Senate committee is going to release a report that was reported in the New York - I'm sorry, the "Washington Post" today about the inspector general at the Department of Homeland Security (COCA, spoken)

In some cases, we are dealing with clarification rather than correction: the description originally provided was correct, but the speaker realizes it may not be specific enough for the addressee to understand her intention; typical markers of clarification are that is or I mean (preceding or following the clarifying information):
a. "Why didn't he, I mean the husband, just kill the snake?" Jenny asked. (COCA, academic)
b. And we will be back shortly with a story about a marathon that takes place on a lake, frozen lake, that is. (COCA, spoken)
c. There are a lot of people who are saying this is wrong - that is, the reaction. (COCA, spoken)

In other cases, ECCs following the host are best regarded as Afterthoughts, i.e. Discourse Acts providing relevant information that only occurs to the speaker when the host is being or has been produced, and which is added after the Nuclear Discourse Act has been expressed; e.g. the motivational if-clause in (53a) or the interpersonal adverbs in (53b) and (53c): 


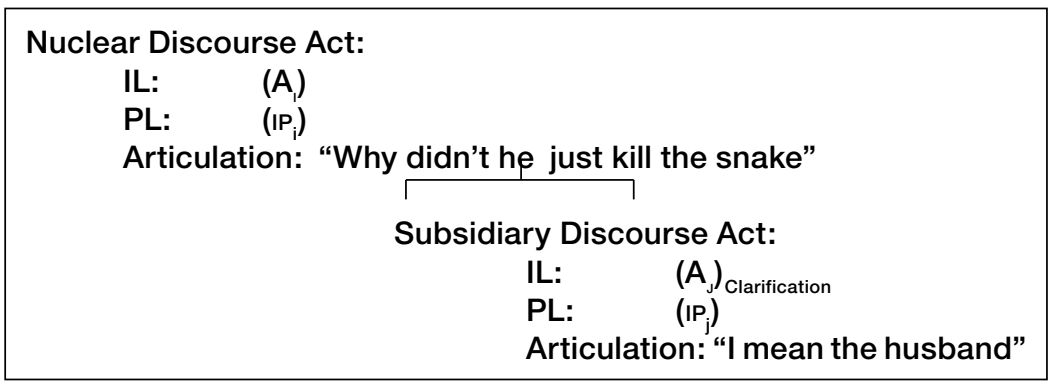

Figure 2: The placement of unplanned ECCs in FDG.

(53)

a. "... You've got the makings of a good veterinary nurse - that's if you're interested." (BYU-BNC, fiction)

b. A: Do they run away again though? B: Sometimes that is the case. Unfortunately. (BNY-BNC, spoken)

c. A: Five more shots were fired. When you got up, you had to realize he was dead? B: I didn't think he was. Honestly. I mean I saw him. (COCA, spoken)

As for their analysis in FDG, it will be clear that since the EEC is not conceptualized and evoked together with the Nuclear Discourse Acts, its position within the Linguistic Expression is triggered at a later stage in the production of the Nuclear Discourse Act, in some cases as late as the articulation phase (as in the case of corrections). This is represented in Figure 2 above for example (52a).

\section{CONCLUSION}

FDG makes use of a very detailed set of rules to account for the linear placement of elements within the clause, phrase and word. Somewhat surprisingly perhaps, little attention has been paid to the placement of ECCs. As is wellknown, these elements are highly mobile; this does not mean, however, that their placement is entirely unpredictable. The present paper has argued that, in those cases where the ECC can be assumed to be part of the overall speaker intention (i.e. conceptualized and evoked at the same time as their host), the linear placement of ECCs is determined by a combination of interpersonal, contextual and processing factors, including the rhetorical or discourse-organizational function of the ECC, the discourse-pragmatic status of either the ECC or elements within the host, the ECC's specific target in the Nuclear Discourse Act, and the ECC's complexity. Although it may be objected that these factors, and the interplay between them, will not unequivocally lead to a specific linear position, the discussion of six different types of ECC (orientational noun phrases, vocatives, motivational if-clauses, non- 
restrictive relative clauses and appositions, and reportative adverbials) has shown that their placement is, in fact, quite systematic, and can be taken care of by the tools offered by FDG.

The second question addressed in the paper was how the placement of ECCs can be integrated in the placement rules of FDG, especially in those cases where the ECC interrupts the host. It has been argued that integration is indeed possible, provided that we accept some minor additions to or modifications of the theory. First, it has been shown that, in addition to the two existing linear extra-clausal positions (preclausal and postclausal), we need a third, interpolated position, to deal with ECCs interrupting the Nuclear Discourse Act. Secondly, it has been argued that all ECCs discussed in this paper need to be analysed as Subsidiary Discourse Acts. This means that also prosodically independent reportative adverbials and illocutionary adverbs, analysed as interpersonal modifiers in the standard approach, will be analysed as separate Discourse Acts. This not only does justice to their nonintegrated status (see also Keizer, "Interpersonal adverbs", "The semantics"), but also avoids the problems otherwise encountered in their placement. Finally, a proposal has been made for the placement of unplanned ECCs, which are regarded as being evoked and expressed during the articulation phase of the Nuclear Discourse Act. Given the fact that these changes are entirely in accordance with the basic principles and general architecture of the model, we may conclude that FDG is able to deal not only with the placement of clausal, but also with the placement of extra-clausal elements. 


\section{WORKS CITED}

Alturo, Núria, Evelien Keizer \& Lluís Payrato, eds. The Interaction Between Context and Grammar in Functional Discourse Grammar. Pragmatics 24(2) (2014) (special issue).

Astruc-Aguilera, Lluïsa. "The Form and Function of Extra-Sentential Elements." Cambridge Occasional Papers in Linguistics 2 (2005): 100-120.

Astruc-Aguilera Lluïsa \& Francis Nolan. "Variation in the Intonation of Extra-Sentential Elements." Segmental and Prosodic Issues in Romance Phonology. Ed. Pilar Prieto, Joan Mascaró \& MariaJosep Solé. Amsterdam\& Philadelphia: John Benjamins, 2007. 85-107.

Biber, Douglas, Stig Johansson, Geoffrey Leech, Susan Conrad \& Edward Finegan. Longman Grammar of Spoken and Written English. Harlow: Longman, 1999.

Blakemore, Diane. Divisions of Labour: The Analysis of Parentheticals. Lingua 116 (2006): 1670-87.

Bolinger, Dwight. Intonation and its Uses. Melody in Grammar and Discourse. London: Arnold, 1989.

Bonami, Olivier \& Danièle Godard. "Lexical Semantics and Pragmatics of Evaluative Adverbs." Adjectives and Adverbs. Syntax, Semantics, Discourse. Ed. Louise McNally \& Christopher Kenned. Oxford: Oxford University Press, 2008. 274-304.

Butler, Christopher S. Structure and Function: A Guide to Three Major Structural-Functional Theories. Amsterdam \& Philadelphia: John Benjamins, 2003.

Chafe, Wallace. "Evidentiality in English Conversation and Academic Writing." Evidentiality: The Linguistic Coding of Epistemology. Ed. Wallace Chafe \& Johanna Nichols. Norwood NJ: Ablex, 1986. 216-272.

Connolly, John H. "Context in Functional Discourse Grammar." Alfa: Revista de Lingüistica 51(2) (2007): 11-33.

Connolly, John H. "The Contextual Component Within a Dynamic Implementation of the FDG Model: Structure and Interaction." Pragmatics 24(2) (2014): 229-248.

Cornish, Francis. "Text and Discourse as Context: Discourse Anaphora and the FDG Contextual Component." The London papers I. Web Papers in Functional Discourse Grammar 82 (2009): 97-115.

Cruttenden, Alan. Intonation (2nd edition). Cambridge: Cambridge University Press, 1997.

Crystal, David. Prosodic Systems and Intonation in English. Cambridge: Cambridge University Press, 1969.

Dall'Aglio Hatther, Marize Mattos \& Kees Hengeveld. "The Grammaticalization of Modal Verbs in Brazilian Portuguese: A Synchronic Approach.” Journal of Portuguese Linguistics 15(1) (2016): 1-14.

Dené, Nicole. “The Relation Between Syntactic and Prosodic Parenthesis." Parentheticals. Ed. Nicole Dehé \& Yordanka Kavalova. Amsterdam: John Benjamins, 2009. 261-284.

Dené, Nicole. Parentheticals in Spoken English: The Syntax-Prosody Relation. Cambridge: Cambridge University Press, 2014.

Dené, Nicole \& Yordanka Kavalova. “The Syntax, Pragmatics, and Prosody of Parenthetical what." English Language and Linguistics 10(2) (2007): 289-320.

Dik, Simon C. The Theory of Functional Grammar. Part I: The Structure of the Clause. 2nd, revised edition. Ed. Kees Hengeveld. Berlin \& New York: Mouton de Gruyter, 1997. 
Dik, Simon C. The Theory of Functional Grammar. Part II: Complex and Derived Constructions. Ed. Kees Hengeveld. Berlin \& New York: Mouton de Gruyter, 1997.

Espinal, Teresa. "The Representation of Disjunct Constituents.” Language 67(4) (1991): 726-762.

Fraser, Bruce. "Pragmatic Markers.” Pragmatics 6 (1996): 167-190.

Geluykens, Roland. "Tails (Right-Dislocation) as a Repair Mechanism in English Conversation." Getting One's Words into Line. Ed. Jan Nuyts \& Georges de Schutter. Dordrecht: Foris, 1987. 119-29.

Gussenhoven, Carlos. The Phonology of Tone and Intonation. Cambridge: Cambridge University Press, 2004.

Haegeman, Liliane. "Parenthetical Adverbials: The Radical Orphanage Approach.” Dislocated Elements in Discourse. Ed. Benjamin Shaer, Philippa Cook, Werner Frey \& Claudia Maienborn. New York and London: Routledge, 2009 [1991]. 331-47. Originally published Aspects of Modern English Linguistics. Ed. Shuki Chiba. Tokyo: Kaitakushi, 1991. 232-54.

Halliday, Michael \& Ruqaiya Hasan. Cohesion in English. London: Longman, 1976.

Halliday, M.A.K. \& Christian M.I.M. Matthiessen. An Introduction to Functional Grammar. $4^{\text {th }}$ edition, revised by Christian M.I.M. Matthiessen. London: Routledge, 2014.

Hannay, Mike \& J. Lachlan Mackenzie. Effective Writing in English. A Resource Guide. Groningen: Martinus Nijhoff, 1996.

Hannay, Mike \& Evelien Keizer. "A Discourse-Treatment of Non-Restrictive Apposition in an FDG of English.” Studies in Functional Discourse Grammar. Ed. María Á. Gómez-González \& J. Lachlan Mackenzie. Berne: Peter Lang, 2005. 159-194.

Hannay Mike \& María de los Ángeles Gómez González. “Thematic Parentheticals in Dutch and English.” Linguistics and the Human Sciences 6 (2012): 99-127.

Heine, Bernd, Gunther Kaltenböck, Tania Kuteva \& Haiping Long. "An Outline of Discourse Grammar." Reflections on Functionalism in Linguistics. Ed. Shannon Bischoff \& Carmen Jeny. Berlin: Mouton de Gruyter, 2013. 155-206.

Hengeveld, Kees. "A Hierarchical Approach to Grammaticalization.” The Grammaticalization of Tense, Aspect, Modality, and Evidentiality: A Functional Perspective. Ed. Kees Hengeveld, Heiko Narrog \& Hella Olbertz. Berlin: de Gruyter Mouton, 2017. 13-37.

Hengeveld, Kees \& J. Lachlan Mackenzie. Functional Discourse Grammar. A Typologically-Based Theory of Language Structure. Oxford: Oxford University Press, 2008.

Hengeveld, Kees \& J. Lachlan Mackenzie. "Grammar and Context in Functional Discourse Grammar.” Pragmatics 24(2) (2014): 203-227.

Huddleston, Rodney, John Payne \& Peter Peterson. "Coordination and Supplementation." The Cambridge Grammar of the English Language. Ed. Rodney Huddleston \& Geoffrey Pullum. Cambridge: Cambridge University Press, 2002. 1273-1362.

Ifantidou, Elly. “Sentential Adverbs and Relevance.” Lingua 90(1/2) (1993): 69-90.

Kaltenböck, Gunther, Evelien Keizer \& Arne Lohmann. "Extra-Clausal Constituents: An Overview." Outside the Clause. The Form and Function of Extra-Clausal Constituents. Ed. Gunther Kaltenböck, Evelien Keizer \& Arne Lohmann. Amsterdam: John Benjamins, 2016. 1-26.

Keizer, Evelien. “The Grammatical-Lexical Dichotomy in Functional Discourse Grammar.” Alfa Revista de Lingüistica 51(2) (2007): 35-56. 
Keizer, Evelien. “The Interpersonal Level in English.” Linguistics 47(4) (2009): 845-866.

KeIzer, Evelien. A Functional Discourse Grammar for English. Oxford: Oxford University Press, 2015.

Keizer, Evelien. "English Partitives in Functional Discourse Grammar: Types and Constraints." Glossa: A Journal of General Linguistics 2(1) (2017): 16.

Keizer, Evelien. "Interpersonal Adverbs in FDG: The Case of frankly." Recent Developments in Functional Discourse Grammar. Ed. Evelien Keizer \& Hella Olbertz. Amsterdam: John Benjamins, 2018. 48-88.

KeIzer, Evelien. "The Semantics, Syntax and Prosody of Adverbs in English: An FDG Perspective." Grammar and Cognition: Dualistic Models of Language Structure and Language Processing. Ed. Gunther Kaltenböck \& Alexander Haselow. Amsterdam: John Benjamins, to appear.

Kroon, Carolien. Discourse Particles in Latin. Amsterdam: Gieben, 1995.

Leech, Geoffrey. "The Distribution and Function of Vocatives in American and British English Conversation." Out of Corpora: Studies in Honour of Stig Johansson. Ed. Hilde Hasselgård \& Signe Oksefjell. Amsterdam: Rodopi, 1999. 107-118.

Levelt, Willem J. M. Speaking. Cambridge, MA: MIT Press, 1989.

Nespor, Marina \& Irene Vogel. Prosodic Phonology. Dordrecht and Riverton NJ: Foris, 1986.

Pullum, Geoffrey K. \& Rodney Huddleston. “Adjectives and Adverbs.” The Cambridge Grammar of the English Language. Ed. Rodney Huddleston \& Geoffrey Pullum. Cambridge: Cambridge University Press, 2002. 525-595.

Pоттs, Christopher. The Logic of Conventional Implicatures. Oxford: Oxford University Press, 2005.

Prince, Ellen. “Toward a Taxonomy of Given/New Information.” Radical Pragmatics. Ed. Peter Cole. New York: Academic Press, 1981. 223-254.

Prince, Ellen. "The ZPG Letter: Subjects, Definiteness, and Information-Status.” Discourse Description Diverse Linguistic Analyses of a Fund-Raising Text. Ed. William C. Mann \& Sandra A. Thompson. Amsterdam: Benjamins, 1992. 295-325.

Quirk, Randolph, Sidney Greenbaum, Geoffrey Leech \& Jan Svartvik. A Comprehensive Grammar of the English Language. London: Longman. 1985.

Schegloff, Emanuel, Gail Jefferson \& Harvey Sacks. "The Preference for Self-Correction in the Organization of Repair in Conversation.” Language 53 (1977): 361-382.

VAn de Velde, Freek. "Interpersonal Modification in the English Noun Phrase." Functions of Language 14 (2007): 203-230.

\section{CORPORA}

Davies, Mark. BYU-BNC. (Based on the British National Corpus from Oxford University Press). http://corpus.byu.edu/bncl. 2004-.

Davies, Mark. The Corpus of Contemporary American English (COCA): 520 million words, 1990-present. http://corpus.byu.edu/coca/. 2008-.

Davies, Mark. News on the Web Corpus (NOW): 5+ billion words from 20 countries, updated every day. http://corpus.byu.edu/now/. 2015-. 
